\title{
Antioxidant Content in Different Parts of Radish (Raphanus sativus L.) from Cold Arid Ladakh region of Trans- Himalaya (Jammu and Kashmir)
}

\section{Sonam Chorol ${ }^{1 *}$}

\section{Sonam Chorol ${ }^{1 *}$ \\ 'DIHAR, DRDO, INDIA. \\ Correspondence \\ Sonam Chorol \\ DIHAR, DRDO, INDIA \\ E-mail: onamnur16@gmail.com \\ History \\ - Submission Date: 18-07-2019; \\ - Review completed: 24-07-2019; \\ - Accepted Date: 01-08-2019.}

DOI : 10.5530/pj.2019.11.166

Article Available online

http://www.phcogj.com/v11/i5

Copyright

(C) 2019 Phcogj.Com. This is an openaccess article distributed under the terms of the Creative Commons Attribution 4.0 International license.

\begin{abstract}
Raphanus sativus (radish) which is consuming in Ladakh from many decades coming as one of the heirloom root vegetables. It is consumed mostly during winter where there is scarcity of vegetables due to prolong cut off from the rest of the world. The aim of this study was done to investigate the phenolic and antioxidant profile in different parts of radish (root. leaf, peel and seed). The aerial part leaves and peel of root of Raphanus sativus L. are always discarded which possess the potent antioxidant properties. The combine (Methanolic and acetone) extract of radish- Sprout was showing the maximum TPC in all the three radish cultivars of Gya Labuk-34.5 \pm 4.9 mgGAE/g DW, Tsentay Labuk-38.5 \pm 6.3 mgGAE/g DW and Pusa Himani- $39.4 \pm 2.6 \mathrm{mgGAE} / \mathrm{g}$ DW) minimum values was for the peel (Gya Labuk-1.7 \pm 0.1 mgGAE/g DW, Tsenaty Labuk-1.8 $\pm 0.1 \mathrm{mg} \mathrm{GAE} / \mathrm{g}$ DW and Pusa Himani-1.9 $\pm 0.3 \mathrm{mgGAE} / \mathrm{g}$ DW statistically significant at $\mathrm{p}<0.05$. FRAP- The maximum values were for the leaf of Gya Labuk-50.1 $\pm 6.19 \mathrm{FeSO}_{4} .7 \mathrm{H}_{2} \mathrm{O} \mathrm{mmol} / \mathrm{g}$. Tsentay Labuk- $61.5 \pm 5.8 \mathrm{FeSO}_{4} .7 \mathrm{H}_{2} \mathrm{O} \mathrm{mmol} / \mathrm{g}$ and Pusa Himani- $8.2 \pm 0.0 \mathrm{FeSO}_{4} .7 \mathrm{H}_{2} \mathrm{O} \mathrm{mmol} / \mathrm{g}$ and minimum values were for the peel of Gya Labuk-2.8 $\pm 0.9 \mathrm{FeSO}_{4} .7 \mathrm{H}_{2} \mathrm{O}$ mmol/g, Tsentay Labuk-2.9 $\pm 1.5 \mathrm{FeSO}_{4} .7 \mathrm{H}_{2} \mathrm{O} \mathrm{mmol} / \mathrm{g}$, Pusa Himani-0.6 $\pm 0.2 \mathrm{FeSO}_{4} .7 \mathrm{H}_{2} \mathrm{O} \mathrm{mmol} / \mathrm{g}$ statistically significant at $\mathrm{p}<0.05$ and in case of DPPH maximum values were for leaf of Gya Labuk- $2.10 \pm 0.16 \mathrm{DPPH} \mathrm{mg} / \mathrm{ml}$, Tsentay Labuk-1.77 \pm $0.09 \mathrm{DPPH} \mathrm{mg} / \mathrm{ml}$, Pusa Himani- $0.25 \pm 0.04 \mathrm{DPPH} \mathrm{mg} / \mathrm{ml}$ and minimum values were for the peel of Gya Labuk-0.06 $\pm 0.01 \mathrm{DPPH} \mathrm{mg} / \mathrm{ml}$, Tsentay Labuk-0.06 $\pm 0.03 \mathrm{DPPH} \mathrm{mg} / \mathrm{ml}$, Pusa Himani-0.02 $\pm 0.01 \mathrm{DPPH} \mathrm{mg} / \mathrm{ml}$ statistically significant at $\mathrm{p}<0.05$. Epidemiological evidence suggests that consumption of vegetables can prevent degenerative diseases caused by oxidative stress. Considering the less data available on antioxidant activity of roots vegetables consumed in area where there is very less production of vegetables due to harsh climatic condition that prevail in the high mountain area such as Ladakh mostly root vegetables are consumed during the winter season as there used to be no vegetables outside only those vegetables having long shelf life is consumed during winter like radish, turnip, carrot, swede, cabbage, etc. Hence leaves and peel which were often discarded possessed a considerable amount of antioxidant and phenolic and can be used as an ingredient in foods.
\end{abstract}

Key words: Raphanus sativus, Heirloom, Antioxidant, Root vegetable.

\section{INTRODUCTION}

Radish (Raphanus sativus L.) is originally from Europe and Asia. ${ }^{1}$ It came to Ladakh via silk route, the traders of Ladakh used to travel via silk route to central Asia for trade from there they collected the seed of vegetables in exchange of goods. The radish, the most common vegetable in the Brassicaceae, is an edible root cultivated worldwide and is one of the most popular root vegetable in Ladakh grown since more than hundred years hence heirloom root vegetable. Consumed as important components in traditional Indian cuisine ${ }^{2,3}$ the radish contains very potent phytochemicals, glucosinolates and breakdown products thereof. ${ }^{4}$ The radish has been used in some societies as laxative, stimulant, digestive aid, appetizer and to treat stomach disorders, traditionally consumed after cooking ${ }^{5}$ in Asia is used to treat gallbladder and hepatic diseases $^{6}$ and to ameliorate the formation of cholesterol gallstones in Mexico. ${ }^{7}$ It is widely grown for its culinary purposes and traditional medicine to support a healthy liver and to promote digestion. ${ }^{8}$ Microgreens is a new class of speciality vegetables that are often harvested at the cotyledonary leaf stage without roots and seed coats.

Microgreens are favoured by chefs and consumers in restaurants for their attractive colours, tender textures and intense flavours. ${ }^{9}$ Microgreens of radish are rich in bioactive compounds relevant to human health. ${ }^{10}$ Edible seeds and sprouts are a good source of antioxidant, such as phenolic acids, flavonoids, trace elements and vitamins. ${ }^{11}$ Sprouts are becoming popular health- food items recommended by dieticians-highly nutritious, low-fat foods, rich in health- promoting phytochemicals, safe and fresh. ${ }^{12}$ Literature is scanty on antioxidant activity and phenolic content of plant foods, specially the vegetables- roots and tubers which are important constituents of Indian diets. ${ }^{13,14}$ Brassicaceae foods are rich in phenolic compounds, vitamins (A, C, E,

Cite this article: Chorol S. Antioxidant Content in Different Parts of Radish (Raphanus sativus L.) from Cold Arid Ladakh region of Trans- Himalaya (Jammu and Kashmir). Pharmacog J. 2019;11(5):1064-70. 
and $\mathrm{K}$ ) and minerals. ${ }^{15}$ Previous studies were conducted on radish root by Wang, Shukla, Lugasi, et al. ${ }^{16-18}$ sprouts $^{19-21}$ leaves and stem. ${ }^{2}$

Therefore in the present study we have determined for the first time to the best of our knowledge in local radish cultivars from Ladakh, it has following two objectives

- To determine the antioxidant activity of different parts of Gya and Tsentay Labuk from Ladakh which are commercially available in Ladakh

- To identity which parts contains the maximum antioxidant

\section{MATERIALS AND METHODS}

Seeds samples were collected from different villages of Ladakh. Seed samples were divided into three groups. The first group were shade dried, grounded in a fine powder for analysis and second group was stored at refrigeration temperature $4^{\circ} \mathrm{C}$ until further analysis. Third group was grown as sprouts. Vegetable that has been consumed in Ladakh since many decades were correlated it with their total phenolic content and antioxidant properties. Samples of leaves were collected from the root which was used for the analysis. Seeds from the second group were germinated up to 7 days so as to get the sprouts, the seeds were grown in the petri dishes with filter paper and distilled water at 25 $\pm 2^{\circ} \mathrm{C}$ for 7 days, before germinating the seeds were rinsed with distilled water and immersed in sodium hypochlorite for $15 \mathrm{~min}$, then drained and washed with distilled water three times. Sprouts were harvested on the $7^{\text {th }}$ day, then shade dried, grinded in a fine powder and stored at refrigerated temperature $\left(4^{\circ} \mathrm{C}\right)$ until further analysis. The third group were sown in the open field of DIHAR in the year 2015 so as to get the root. The seeds were sown on the ridges of $15 \mathrm{~cm}$ high and in the plot of $2.5 \times 3 \mathrm{~m}$. Harvested roots were washed, shade dried, grinded in a fine powder and stored at refrigerated temperature $\left(4^{\circ} \mathrm{C}\right)$ until further analysis. The harvested root were washed properly three times, with tap water two times and one time distilled afterward the peel were peeled off from the root for the analysis, then shade dried and grind in a fine powder for further analysis and stored at refrigerated temperature $\left(4^{\circ} \mathrm{C}\right)$. The grounded samples collected from different villages were used for the analysis. The seeds were shade dried and grind into fine powder.

\section{Chemicals and reagents}

Solvents and Folin-Ciocalteu reagent were purchased from Merck, Germany; 1, 1-diphenyl-2-picrylhydrazyl radical (DPPH), 2, 4, 6-tripyridyl-s-triazine (TPTZ), gallic acid, and ferrous sulfate hexahydrate were purchased from Sigma-Aldrich, USA. All other chemicals were of analytical grade.2, 2-diphenyl-1-picryl hydrazyl (DPPH), gallic acid, 2, 4, 6-tripyridyl-s-triazine (TPTZ) and ferric chloride were obtained from Sigma Chemical Inc., USA. All other reagents and chemicals used were of analytical grade procured from local sources. Distilled water was used in the study.

\section{Sample collection and extraction}

The seeds of two local cultivars Raphanus sativus L. (Gya Labuk and Tsentay Labuk) were collected from the different places of Ladakh and the one which was used as control was collected from the IARI, New Delhi as Pusa Himani, the voucher specimen for the two local cultivars were deposited in the herbarium of the Botanical Survey Of India, Dehradun with accession number. Seeds that were collected from different areas, the seeds were sown in the DIHAR field in year 2015 having five replications, root, leaf, peel and pulp were separated for analysis from each sample having three replicates. The samples were shade dried after the harvest and the samples were ground in mortar and pistil in powder form for further analysis. Shade dried powdered seed samples were defatted with hexane followed by two cycles of extraction with methanol and two cycles of acetone afterward. Each sample (20-
$90 \mathrm{mg})$ was extracted $(\mathrm{n}=3)$ for $15 \mathrm{~min}$ with $1.5 \mathrm{ml}$ methanol in a $2 \mathrm{ml}$ micro centrifuge tube and vortexes at room temperature. The sample was centrifuged at $5600 \mathrm{~g}$ for $10-15 \mathrm{~min}$ and the supernatant was recovered. The residue was mixed with $1.5 \mathrm{ml}$ of acetone and the process was repeated as described above. TPC, TAC were measured directly into methanolic and acetone and the values were combined mathematically.

\section{Antioxidant capacity (DPPH radical scavenging activity)}

Free radical scavenging method by DPPH developed by Brand-Williams et al. was followed with minor modification. A $0.1 \mathrm{mmol} / \mathrm{l}$ solution of DPPH in methanol was prepared and briefly $300 \mu \mathrm{l}$ of the solution was treated with $15 \mu \mathrm{l}$ of the methanolic and acetone extracted sample and a control was treated with $15 \mu \mathrm{l}$ of solvent instead of the extract and the mixture allowed to stand at room temperature for $30 \mathrm{~min}$ before the absorbance was recorded at $517 \mathrm{~nm}$. Antioxidant value was expressed as $\mathrm{IC}_{50}$, the amount of sample extracted into $1 \mathrm{ml}$ solution necessary to decrease by $50 \%$ the initial DPPH concentration $\mathrm{IC}_{50}$ was derived from the $\%$ disappearance vs. concentration plot $(\mathrm{mg} / \mathrm{ml})$.

\section{FRAP}

Ferric reducing antioxidant power (FRAP) was determined in sample extracts according to Benzie and Strain (1999) and Korekar, et al. 2012 with minor modifications. This method is based on the ability of the sample to reduce $\mathrm{Fe}^{3+}$ to $\mathrm{Fe}^{2+}$ ions. In the presence of TPTZ, the Fe $2^{+}-$ TPTZ complex exhibits blue colour which is read at $593 \mathrm{~nm}$. A total of $7.5 \mu \mathrm{l}$ of extract and $22.5 \mu \mathrm{l}$ of distilled water were added to $225 \mu \mathrm{l}$ of freshly prepared FRAP reagent ( 10 parts of $300 \mathrm{mmol} / \mathrm{l}$ sodium acetate buffer at $\mathrm{pH} 3.6$, one part of $10 \mathrm{mmol} / \mathrm{l} \mathrm{TPTZ}$ solution and one part of $20 \mathrm{mmol} / \mathrm{l} \mathrm{FeCl}_{3} \cdot 6 \mathrm{H}_{2} \mathrm{O}$ ) and the reaction mixture was incubated for $30 \mathrm{~min}$. The increase in absorbance was measured at $593 \mathrm{~nm}$ against FeSO4 as standard. The calibration equation for $\mathrm{FeSO}_{4} \cdot 7 \mathrm{H}_{2} \mathrm{O}$ was $\mathrm{y}=$ $0.001 \mathrm{x}+0.145, \mathrm{R}^{2}=0.980$ where $\mathrm{y}$ is the absorbance at $593 \mathrm{~nm}$ and $\mathrm{x}$ is the concentration of $\mathrm{FeSO}_{4} \cdot 7 \mathrm{H}_{2} \mathrm{O}$ in $\mathrm{mmol} \mathrm{Fe}$ (II)/g DW.

\section{Determination of total phenolic content}

Total phenolic content (TPC) were determined in sample extracts using the Folin- Ciocalteu reagent and the values are expressed as equivalents of gallic acid, which is the most commonly used standard in phenolic estimations since gallic acid found to be more stable and pharmacologically active antioxidant. The Folin-Ciocalteu reagent assay was used to determine the TPC. An aliquot of the samples (30 $\mu \mathrm{l})$ was introduced into 96 well ELISA plate followed by $150 \mu \mathrm{l}$ FolinCiocalteu reagent, which was previously diluted with distilled water (1:10) and $120 \mu \mathrm{l}$ sodium carbonate $(7.5 \% \mathrm{w} / \mathrm{v})$. The ELISA plates covered with parafilm and allowed to stand for $30 \mathrm{~min}$ in ELISA reader. The absorbance was recorded at $765 \mathrm{~nm}$ in an ELISA reader (Spectro Max M2 e, Molecular Devices, Sunnyvale, CA, United States). TPC was expressed in gallic acid equivalents (GAE $\mathrm{mg} / \mathrm{g}$ ). The calibration equation for gallic acid was $y=0.009 x+0.134\left(R^{2}=0.998\right)$ where $y$ is the absorbance at $765 \mathrm{~nm}$ and $\mathrm{x}$ is the concentration of gallic acid in $\mathrm{mg} / \mathrm{l}$.

\section{Statistical analysis}

Data is expressed on dry weight basis and is presented as mean $\pm \mathrm{SD}$. Two-tailed Pearson correlation was done to estimate the strength of association between total phenolic content and antioxidant capacity. The effect of variety, different parts and their interaction on total phenolic content and antioxidant capacity were performed by Analysis Of Variance (ANOVA) test using the general linear model GLM. Turkey's honest significance test was carried out at a $95 \%$ confidence level ( $p \leq 0.05)$ and the difference in levels of antioxidant capacities between hydrophilic and lipophilic fractions were statistically analyzed by Wilcoxon rank sum test and all data was performed using SPSS 17.0 version. 


\section{RESULTS}

Two assays were used to assess the antioxidant capacity in different parts of radish: FRAP, DPPH and total phenolic content (Tables 1-3). The Wilcoxon results were shown in Table 4. In the two assay (FRAP and TPC), statistically significant difference at $\mathrm{p}<0.05$ was detected for the two extraction solvents, and the antioxidant capacity of hydrophilic fraction was higher than lipophilic fraction with high mean $\pm \mathrm{SD}(\mathrm{p}<$ $0.05)$.

The radical scavenging effects of different parts of radish are represented in Table 2 with mean \pm SD $(\mathrm{p}<0.05)$. The different parts used were able to reduce the stable, purple coloured DPPH radical reaching $50 \%$ of reduction. The maximum and minimum $\mathrm{IC}_{50}$ value was $2.10 \pm 0.16 \mathrm{mg} /$ $\mathrm{ml}, 0.02 \pm 0.00 \mathrm{mg} / \mathrm{ml}$ respectively for leaf of Gya Labuk and peel of Pusa Himani showing a significant value $(\mathrm{p}<0.05)$. The values ranged from 0.06-2.10 (Gya Labuk), 0.06-1.77 (Tsentay Labuk), 0.02-0.25
(Pusa Himani) which showed 1-35, 1-29.5 and 1-12.5 folds variation respectively.

The antioxidant activity of different parts of radish using FRAP assay with mean \pm SD $(\mathrm{p}<0.05)$ was shown in Table 1 . The FRAP content in the different parts of radish in Gya Labuk ranged from $2.8 \pm 0.9$ to $50.1 \pm 6.1$ were in peel and leaf respectively which showed 1-17.9 fold variation between the parts. In case of Tsentay Labuk the value ranged from $2.9 \pm 1.5$ to $61.5 \pm 5.8$ were in peel and leaf respectively which showed 1- 21.2 fold having a significant value at $p<0.05$ and in case of Pusa Himani the value ranged from $0.6 \pm 0.2$ to $8.2 \pm 0.0$ which were in peel and leaf respectively which showed $1-13.7$ fold variation.

The antioxidant activity of different parts of radish using TPC assay with mean \pm SD was shown in the Table 5. In case of Gya Labuk the value ranged from $1.7 \pm 0.1$ to $34.5 \pm 4.9$ for peel and sprout respectively which were significantly different, in case of Tsentay Labuk the value

Table 1: Antioxidant capacity in different parts of radish (FRAP, $\mathrm{FeSO}_{4} .7 \mathrm{H}_{2} \mathrm{O} \mathrm{mmol} / \mathrm{g} \mathrm{DW}$ ) $* \mathrm{p}<0.0$ level.

\begin{tabular}{|c|c|c|c|c|c|}
\hline S.N & Cultivar & Parts & Methanol & Acetone & Combine \\
\hline 1 & $\begin{array}{l}\text { Raphanus sativus L. } \\
\text { (Gya labuk) }\end{array}$ & Root & $10.5 \pm 1.2^{\mathrm{c}}$ & $3.8 \pm 0.2^{c}$ & $14.4 \pm 1.2^{\mathrm{b}}$ \\
\hline 2 & & Leaf & $48.2 \pm 6.6^{\mathrm{e}}$ & $3.9 \pm 2.4^{c}$ & $50.1 \pm 6.1^{\mathrm{d}}$ \\
\hline 3 & & Sprout & $25.5 \pm 0.6^{d}$ & $1.9 \pm 0.08^{\mathrm{b}}$ & $44.6 \pm 1.7^{c}$ \\
\hline 4 & & Seed & $7.1 \pm 1.8^{\mathrm{b}}$ & $4.2 \pm 1.1^{\mathrm{c}}$ & $11.3 \pm 1.9^{b}$ \\
\hline 5 & & Peel & $2.4 \pm 0.8^{\mathrm{a}}$ & $0.4 \pm 0.0^{\mathrm{a}}$ & $2.8 \pm 0.9^{a}$ \\
\hline 6 & & Average & $15.9 \pm 15.1$ & $3.1 \pm 1.8$ & $30.9 \pm 19.7$ \\
\hline 1 & $\begin{array}{l}\text { Raphanus sativus L. } \\
\text { (Tsentay labuk) }\end{array}$ & Root & $12.0 \pm 4.9^{\mathrm{b}}$ & $3.8 \pm 0.5^{b}$ & $15.7 \pm 4.9^{\mathrm{b}}$ \\
\hline 2 & & Leaf & $50.3 \pm 4.8^{\mathrm{d}}$ & $11.1 \pm 6.0^{c}$ & $61.5 \pm 5.8^{\mathrm{d}}$ \\
\hline 3 & & Sprout & $29.9 \pm 2.0^{c}$ & $5.6 \pm 0.1^{\mathrm{b}}$ & $29.9 \pm 14.2^{\circ}$ \\
\hline 4 & & Seed & $8.0 \pm 3.0^{\mathrm{ab}}$ & $4.2 \pm 1.3^{\mathrm{b}}$ & $12.3 \pm 2.7^{\mathrm{b}}$ \\
\hline 5 & & Peel & $2.5 \pm 1.5^{\mathrm{a}}$ & $0.4 \pm 0.1^{\mathrm{a}}$ & $2.9 \pm 1.5^{\mathrm{a}}$ \\
\hline 6 & & Average & $25.0 \pm 18.8$ & $5.7 \pm 4.2$ & $28.8 \pm 21.4$ \\
\hline 1 & $\begin{array}{l}\text { Raphanus sativus L. } \\
\text { (Pusa Himani) }\end{array}$ & Root & $2.7 \pm 0.7^{\mathrm{b}}$ & $0.1 \pm 0.0^{\mathrm{a}}$ & $2.8 \pm 0.7^{c}$ \\
\hline 2 & & Leaf & $7.4 \pm 0.0^{\mathrm{e}}$ & $0.7 \pm 0.1^{\mathrm{c}}$ & $8.2 \pm 0.0^{\mathrm{e}}$ \\
\hline 3 & & Sprout & $4.9 \pm 0.7^{\mathrm{d}}$ & $1.7 \pm 0.5^{\mathrm{d}}$ & $6.6 \pm 0.9^{\mathrm{d}}$ \\
\hline 4 & & Seed & $1.7 \pm 0.5$ & $0.4 \pm 0.1^{\mathrm{b}}$ & $2.0 \pm 0.6^{\mathrm{b}}$ \\
\hline 5 & & Peel & $0.5 \pm 0.2^{\mathrm{a}}$ & $0.0 \pm 0.0^{\mathrm{a}}$ & $0.6 \pm 0.2^{\mathrm{a}}$ \\
\hline 6 & & Average & $3.5 \pm 2.5^{c}$ & $0.6 \pm 0.7$ & $4.0 \pm 3.0$ \\
\hline
\end{tabular}

Table 2: Antioxidant capacity in different parts of radish (DPPH, $\mathrm{mg} / \mathrm{ml}$ ) $\mathrm{p}<0.05$ level.

\begin{tabular}{cccc}
\hline S.N & Cultivar & Parts & DPPH $(\mathrm{mg} / \mathrm{ml})$ \\
\hline 1 & Raphanus sativus L. (Gya Labuk) & Root & $0.81 \pm 0.09^{\mathrm{b}}$ \\
& Leaf & $2.10 \pm 0.16^{\mathrm{e}}$ \\
& Sprout & $1.80 \pm 0.10^{\mathrm{d}}$ \\
& Seed & $0.92 \pm 0.08^{\mathrm{c}}$ \\
& Peel & $0.06 \pm 0.01^{\mathrm{a}}$ \\
& Raphanus sativus L. (Tsentay Labuk) & Average & $1.14 \pm 0.74$ \\
& Root & $0.61 \pm 0.14^{\mathrm{b}}$ \\
& Leaf & $1.77 \pm 0.09^{\mathrm{d}}$ \\
& Sprout & $1.35 \pm 0.37^{\mathrm{c}}$ \\
& Seed & $0.79 \pm 0.06^{\mathrm{b}}$ \\
& & $0.06 \pm 0.03^{\mathrm{a}}$ \\
& & Peel & $0.92 \pm 0.63$ \\
& Raphanus sativus L. (Pusa Himani) & Root & $0.14 \pm 0.02^{\mathrm{c}}$ \\
& Leaf & $0.25 \pm 0.04^{\mathrm{e}}$ \\
& Sprout & $0.19 \pm 0.05^{\mathrm{d}}$ \\
& Seed & $0.05 \pm 0.01^{\mathrm{b}}$ \\
& & Peel & $0.02 \pm 0.01^{\mathrm{a}}$ \\
\end{tabular}


Table 3: Show the correlations between the parts, antioxidant activity and TPC.

\begin{tabular}{ccccccc}
\hline & Part & Cultivar & IC & FRAP & TPC \\
\hline${ }^{1}$ Part & 1 & .000 & $-.633^{* *}$ & -.077 & $.664^{* *}$ \\
${ }^{2} \mathrm{IC}_{50}$ & - & - & 1 & -.199 & $-.276^{*}$ \\
${ }^{3}$ FRAP & - & - & - & 1 & $.312^{* *}$ \\
${ }^{4}$ TPC & - & - & - & - & 1 \\
\hline
\end{tabular}

${ }^{*}$ Correlation is significant at the 0.01 level (2-tailed); ${ }^{*}$ Correlation is significant at the 0.05 level (2-tailed); ${ }^{1}$ Part (root, leaf, sprout, seed and peel); ${ }^{2} \mathrm{C}_{50}$ : Inhibitory concentration, the amount of sample extract into $1 \mathrm{ml}$ solution necessary to decrease by $50 \%$ the initial DPPH concentration; ${ }^{3} \mathrm{FRAP}$ : Ferric reducing antioxidant potential (FeSO $\left.7 \mathrm{H}_{2} \mathrm{O} \mathrm{mmol} / \mathrm{g} \mathrm{DW}\right) ;{ }^{4} \mathrm{TPC}$ : Total phenolic content (mg GAE/g DW).

Table 4: Comparison of the antioxidant activity levels and phenolic contents of hydrophilic and lipophilic fractions ( $\mathrm{n}=50$ ) Wilcoxson Rank Sum Test.

\begin{tabular}{|c|c|c|c|c|c|}
\hline Item & Cultivar/Variety & Fraction & Mean \pm SD & $\mathrm{Z}$ & $P$ \\
\hline \multirow{6}{*}{ FRAP } & \multirow{2}{*}{ Gya Labuk } & Hydrophilic & $18.4 \pm 16.04$ & \multirow[t]{2}{*}{-.615} & \multirow[t]{2}{*}{$\mathrm{P}<0.000$} \\
\hline & & Lipophilic & $2.6 \pm 1.5$ & & \\
\hline & \multirow{2}{*}{ Tsentay Labuk } & Hydrophilic & $24.4 \pm 21.5$ & \multirow[t]{2}{*}{-.588} & \multirow[t]{2}{*}{$\mathrm{P}<0.000$} \\
\hline & & Lipophilic & $5.9 \pm 5.7$ & & \\
\hline & \multirow{2}{*}{ Pusa Himani } & Hydrophilic & $3.5 \pm 2.5$ & \multirow[t]{2}{*}{-.612} & \multirow[t]{2}{*}{$\mathrm{P}<0.000$} \\
\hline & & Lipophilic & $0.59 \pm 0.64$ & & \\
\hline \multirow{3}{*}{ TPC } & \multirow{2}{*}{ Gya Labuk } & Hydrophilic & $17.1 \pm 11.2$ & \multirow[t]{2}{*}{-.612} & \multirow[t]{2}{*}{$\mathrm{P}<0.000$} \\
\hline & & Lipophilic & $3.6 \pm 3.5$ & & \\
\hline & Tsentay Labuk & Hydrophilic & $12.3 \pm 10.2$ & -.609 & $\mathrm{P}<0.000$ \\
\hline
\end{tabular}

Table 5: Total phenolic content in different parts of radish (mg GAE/g DW) *p $<0.05$ level.

\begin{tabular}{|c|c|c|c|c|c|}
\hline$S$ & Cultivar & Parts & Methanol & Acetone & Combine \\
\hline 1 & $\begin{array}{l}\text { Raphanus sativus L. } \\
\text { (Gya labuk ) }\end{array}$ & Root & $9.6 \pm 1.9^{b}$ & $2.0 \pm 0.4^{\mathrm{b}}$ & $11.6 \pm 2.2^{\mathrm{b}}$ \\
\hline 2 & & Leaf & $20.2 \pm 7.4^{\mathrm{d}}$ & $3.6 \pm 0.5^{c}$ & $23.8 \pm 1.0^{c}$ \\
\hline 3 & & Sprout & $31.4 \pm 3.7^{\mathrm{e}}$ & $3.1 \pm 2.4^{\mathrm{c}}$ & $34.5 \pm 4.9^{\mathrm{d}}$ \\
\hline 4 & & Seed & $17.0 \pm 3.2^{\mathrm{c}}$ & $9.6 \pm 1.9^{d}$ & $26.6 \pm 3.2^{\mathrm{c}}$ \\
\hline 5 & & Peel & $1.7 \pm 0.1^{\mathrm{a}}$ & $0.6 \pm 0.1^{\mathrm{a}}$ & $1.7 \pm 0.1^{\mathrm{a}}$ \\
\hline 6 & & Total & $19.1 \pm 10.3$ & $4.0 \pm 3.2$ & $23.0 \pm 11.2$ \\
\hline 1 & $\begin{array}{l}\text { Raphanus sativus L. } \\
\text { (Tsentaylabuk) }\end{array}$ & Root & $8.5 \pm 2.3^{c}$ & $2.1 \pm 0.7^{\mathrm{ab}}$ & $10.6 \pm 2.9^{b}$ \\
\hline 2 & & Leaf & $15.6 \pm 1.9^{\mathrm{d}}$ & $11.2 \pm 3.2^{c}$ & $26.8 \pm 2.6^{c}$ \\
\hline 3 & & Sprout & $29.0 \pm 2.4^{\mathrm{e}}$ & $9.4 \pm 5.6^{c}$ & $38.5 \pm 6.3^{\mathrm{d}}$ \\
\hline 4 & & Seed & $4.5 \pm 1.0^{\mathrm{b}}$ & $3.8 \pm 0.05^{\mathrm{b}}$ & $8.3 \pm 0.2^{\mathrm{b}}$ \\
\hline 5 & & Peel & $1.8 \pm 0.1^{\mathrm{a}}$ & $0.6 \pm 0.6^{\mathrm{a}}$ & $1.8 \pm 0.1^{\mathrm{a}}$ \\
\hline 6 & & Total & $11.6 \pm 10.1$ & $5.1 \pm 4.6$ & $16.6 \pm 13.6$ \\
\hline 1 & $\begin{array}{l}\text { Raphanus sativus L. } \\
\text { (Pusa Himani) }\end{array}$ & Root & $4.9 \pm 0.9^{b}$ & $2.5 \pm 0.8^{\mathrm{ab}}$ & $7.4 \pm 1.6^{b}$ \\
\hline 2 & & Leaf & $21.9 \pm 1.2^{\mathrm{d}}$ & $14.7 \pm 1.5^{\mathrm{d}}$ & $36.6 \pm 2.6^{\mathrm{d}}$ \\
\hline 3 & & Sprout & $23.9 \pm 2.3^{\mathrm{e}}$ & $15.5 \pm 2.0^{\mathrm{d}}$ & $39.4 \pm 2.6^{\mathrm{e}}$ \\
\hline 4 & & Seed & $8.9 \pm 1.3^{\mathrm{c}}$ & $5.3 \pm 1.5^{c}$ & $14.2 \pm 2.7^{c}$ \\
\hline 5 & & Peel & $1.3 \pm 0.2^{\mathrm{a}}$ & $0.6 \pm 0.1^{\mathrm{a}}$ & $1.9 \pm 0.3^{\mathrm{a}}$ \\
\hline 6 & & Total & $16.5 \pm 16.0$ & $13.1 \pm 14.6$ & $19.9 \pm 15.6$ \\
\hline
\end{tabular}

ranged from $1.8 \pm 0.1$ to $38.5 \pm 6.3$ for peel and sprout respectively which were also significantly different at $\mathrm{p}<0.05$ and in case of Pusa Himani the value ranged from $1.9 \pm 0.3$ to $39.4 \pm 2.6$ for peel and sprouts respectively which were significantly different and which showed 120.3, 1- 21.4 and $1-20.7$ fold variations respectively.

\section{DISCUSSION}

The solvent used methanol and acetone, as these two solvents extract possessed significant amount of polyphenolics and showed potent antioxidant and their potency was in the order of methanol $>$ acetone $>$ ethyl acetate $>$ water $>$ chloroform $>$ hexane. ${ }^{2}$ Beevi et al. ${ }^{2}$ reported ferric scavenging activity in leaves and stem of radish with methanolic extract at range of $0.02-0.05 \mathrm{mg} / \mathrm{ml}$ and $0.06-0.1 \mathrm{mg} / \mathrm{ml}$ respectively.
A comparison between the DPPH radical scavenging activities of Raphanus sativus L. and some culinary spices such as ginger, basil, and parsley showed that the leaves and stem of Raphanus sativus L. were more potent in terms of radical scavenging activity whereby their IC50 were comparatively much lower than these culinary spices. ${ }^{22,23} \mathrm{~A}$ comparison between DPPH radical scavenging activity of Raphanus sativus $\mathrm{L}$. and common cruciferous vegetables showed that the root of radish was more potent in terms of radical scavenging activity whereby $\mathrm{IC}_{50}$ was comparatively much lower than these cruciferous vegetables. ${ }^{24}$ Tiveron et al. ${ }^{25}$ reported that the amount of $\mathrm{DPPH}\left(\mathrm{IC}_{50}\right)$ for lettuce (17.07 mg.ml), artichoke (18.14 mg/ml), turmeric $(21.14 \mathrm{mg} / \mathrm{ml})$ spinach $(22.87 \mathrm{mg} / \mathrm{ml})$ which were higher than our result, in case of lowest $\mathrm{IC}_{50}$ values better in terms of antioxidant activity. 
The FRAP assay is one the most simple, rapid, inexpensive tests and very useful method for routine analysis of antioxidant. The FRAP assay is developed for direct test of total antioxidant power of a phytochemicals exhibited redox properties, which played a crucial role in determining the antioxidant properties ${ }^{26}$ showing a significant value at $\mathrm{p}<0.000$. Tiveron et al. ${ }^{25}$ reported that ability to reduce $\mathrm{Fe}^{3+}$ to $\mathrm{Fe}^{2+}$ in radish was $0.09 \mathrm{mmol} \mathrm{Fe}^{2+} / \mathrm{g} \mathrm{DW}$ which showed much lower ability than our result of all the parts. Beevi et al. ${ }^{2}$ reported $4.7 \pm 0.12 \mathrm{mmol} \mathrm{FeSO}_{4} / \mathrm{g}$ in methanolic extract and $2.7 \pm 0.2 \mathrm{mmol} \mathrm{FeSO}_{4} / \mathrm{g}$ in acetone extract in case of leaf of radish.

It is well known that phenolic compounds are generally synthesized via the phenylpropanoid metabolism pathway, in which L- phenylalanine is converted into trans-cinnnamic acid by the enzyme phenylalanine ammonia lyase and some other phenolic compounds are subsequently produced, such as chlorogenic acid. ${ }^{11}$ Phenolic compounds acts as important antioxidants and they can be oxidized to quinone during oxidative stress. Therefore, the TPC value assayed actually depends on the balance of synthesis and oxidation, the phenolic compounds being the major antioxidant of Brassica plants and it has been shown that the antioxidant capacity of Brassica vegetables is higher compared to other vegetable crops. The total phenolic content in seed ranged between 8 and $11 \mathrm{mg} \mathrm{GAE} / \mathrm{g}$ DW, in sprouts between 14 and $20 \mathrm{mg} \mathrm{GAE} / \mathrm{g} \mathrm{DW}$, and in root between 4 and $5 \mathrm{mg} \mathrm{GAE} / \mathrm{g}$ DW were obtained by Bors et al. ${ }^{27}$ Lower level of total phenolic content were obtained by Pajak et al. ${ }^{28}$ in radish seeds ( $6 \mathrm{mg} \mathrm{GAE} / \mathrm{g} \mathrm{DW})$, sprouts $(\sim 12.5 \mathrm{mg} \mathrm{GAE} / \mathrm{g} \mathrm{DW})$. The total polyphenolic content reported for black kale leaves (1366 $\mathrm{mg} / \mathrm{g})^{29}$ and ginger rhizome $(0.05-.98 \mathrm{mg} / \mathrm{g})$ by Bozin et al..$^{22}$ appeared to be much lesser than that of leaves and stem of Raphanus sativus $\mathrm{L}$. In addition, the polyphenolic content of leaves was almost comparable to the phenolic content of traditionally rich sources such as black tea $(81-135 \mathrm{mg} / \mathrm{g})$ and green tea $(66-106 \mathrm{mg} / \mathrm{g}) .^{30}$ It has been proven that phenolic and flavonoids compounds present in the plants are mainly responsible for antioxidant activity. ${ }^{31}$ Phenolic compounds in seeds were significantly higher in content and variability than in sprouts from $\sim 3778 \mathrm{mg} / 100 \mathrm{~g}$ FW in radish and $\sim 1149 \mathrm{mg} / 100 \mathrm{~g}$ FW in kohlrabi. ${ }^{32}$ The polyphenolics seemed to be more concentrated in the discarded parts of the vegetables such as leaves, stem than in their edible parts ${ }^{2}$ likewise more flavonoid contents in the leaves of cauliflower than in the edible parts ${ }^{33}$ and also in the leaves and seed of the black cabbage. ${ }^{28}$

\section{Correlation between different parts, cultivar, DPPH, FRAP and TPC}

There was negative correlation between parts of radish and $\mathrm{IC}_{50}(\mathrm{r}=-$ $0.633)$ and positive correlation with TPC and FRAP $(r=0.512)$. The same result was found by Korekar et al. in apricot kernel, Bors et al., in radish $(\mathrm{r}=0.939, \mathrm{p}<0.001)$.

Wilcoxon test: Table 05 shows there was a significant difference between the hydrophilic and lipophilic extraction in case of the FRAP assay for Gya Labuk $(\mathrm{Z}=-0.615, \mathrm{p}=0.000)$, Tsentay Labuk $(\mathrm{Z}=-0.588, \mathrm{p}=0.000)$, Pusa Himani $(Z=-0.612, p=0.000)$. For the phenolic content also there was a significant difference between the two extraction solvents, Gya Labuk $(\mathrm{Z}=-0.612, \mathrm{p}=0.000)$, Tsentay Labuk $(\mathrm{Z}=-0.609, \mathrm{p}=0.000)$, Pusa Himani $(Z=-0.612, p=0.000) .^{34,35}$

\section{CONCLUSION}

Most of the vegetables are seasonal crops having rich source of nutrient, fibers, minerals and phenolic contents, the vegetables which are out of season are grown under artificial conditions which resulted in a decline of its nutrient value of vegetables and the place like Ladakh, where there used to be no vegetables in the open has to import from different places which is one of the factor for decline in its nutrient values, therefore the sprouts become the one of the alternative for vegetables during winter having higher nutrient profile than other parts of vegetables like radish.
This study showed that radish sprouts have higher amount of phenolic content and higher antioxidant capacity than its other parts - peel, root, leaf and seed. The radish sprouts can be used as dietary supplements.

\section{ACKNOWLEDGEMENT}

The author thanks to DIHAR, DRDO for financial support in the form of fellowship awards.

\section{CONFLICTS OF INTEREST}

None.

\section{REFERENCES}

1. Gutierrez RM, Perez RL. Raphanus sativus (Radish): Their chemistry and biology. Scientific World Journal. 2004;4:811-37.

2. Beevi SS, Narasu ML, Gowda BB. Polyphenolics profile, antioxidant and radical scavenging activity of leaves and stem of Raphanus sativus. Plant Foods Hum Nutr. 2010;65:8-17

3. Richfort S, Panozzo J. Phytochemicals for health, the role of pulses. Journal of Agricultural and Food Chemistry. 2007;55:7981-94

4. Mithen R, Bennet R, Marquez J. Glucosinolatebiochemical diversity and innovation in the Brassicales. Phytochemistry. 2010;71:2074-86.

5. Gilani AH, Ghayur MN. Pharmacological basis for the gut stimulatory activity of Raphanus sativus leaves. J Ethano Pharmacol. 2004;95:169-72.

6. Baek SH, Park M, Suth JH, Choi HS. Protective effects of an extract of young radish (Raphanus sativus L.) cultivated with sulphur (sulphur radish extract) and of sulforaphane on carbon tetrachloride-induced hepatotoxicity. Biosci Biotech Biochem. 2008;72:1176-82

7. Castro-Torres IG, De la OAM, Gallegos- Estudillo J, Naranjo-Rodriguez EB, Dominguez Ortiz MA. Raphanus sativus L. var niger as a source of phytochemicals for the prevention of cholesterol gallstones. Phyto Other Res. 2014;28:167-71

8. Nadkarni KM. Indian material medica. Popular Prakashan, Bombay. 1976.

9. Xiao Z, Lesten GE, Lou Y, Kou L, Yang I, Wang Q. Postharvest quality and shelf life of radish microgreens as impacted by storage temperature, packaging film and chlorine wash treatment. LWT Food Science and Technology. 2013;55(2):551-8.

10. Xiao Z, Lesten GE, Lou Y, Wang $Q$. Assessment of vitamin and carotenoid concentration of emerging food products:Edible microgreens. Journal of Agriculture and Food Chemistry. 2012;60(31):7644-51.

11. Pasko P, Barton H, Zagrodzki P, Gorinstein S, Folta M, Zachwieja Z Anthocyanins, total polyphenols and antioxidant activity in amaranth and quinoa seeds and sprouts during their growth. Food Chemistry. 2009;115:994-8.

12. Martinez-Villaluenga C, Penas E, Ciska E, Piskula MK, Kozlowska H, VidalValverde $C$, et al. Time dependence of bioactive compounds and antioxidant capacity during germination of different cultivars of broccoli and radish seeds. Food Chemistry. 2010;120:710-6.

13. Stratil $P$, Klejdus $B$, Kuban $V$. Determination of total content of phenolic compounds and their antioxidant activity in vegetables -Evaluation of spectrophotometric methods. Journal of Agricultural and Food Chemistry 2006;54:607-16.

14. Sreeramulu D, Raghunath M. Antioxidant activity and phenolic content of roots, tubers and vegetables commonly consumed in India. Food Research International. 2010;43:1017-20.

15. Jahangir M, Kim HK, Choi YH, Verpoorte R. Health affecting compounds in Brassicaceae. Compr Rev Food Sci Food Safety. 2009;8:31-43.

16. Wang LS, Sun XD, Cao Y, Wang L, Li FJ, Wang YF. Antioxidant and prooxidant properties of acylated pelargonidin derivatives extracted from red radish (Raphanus sativus var. niger, Brassicaceae). Food Chem Toxicol. 2010;48(10):2712-816

17. Shukla S, Chatterji S, Mehta S, Rai PK, Singh RK, Yadav DK, et al. Antidiabetic effect of Raphanus sativus root juice. Pharm Biol. 2011;49(1):32-7.

18. Lugasi A, Blazovics A, Hagymasi K, Kocsis I, Kery A. Antioxidant effect of squeezed juice from black radish (Raphanus sativus $L$. var niger) in alimentary hyperlipidaemia in rats. Phytother Res. 2005;19(7):587-91.

19. Papi A, Orlandi M, Bartolini G, Barillari J, lori R, Paolini M, et al. Cytotoxic and antioxidant activity of 4-methylthio-3-butenyl isothiocyanate fromRaphanus sativusL. (Kaiware Daikon) sprouts. J Agric Food Chem. 2008;56(3):875-83. 
20. Lee SO, Lee IS. Induction of quinone reductase, the phase 2 anticarcinogenic marker enzyme, in Hepa1c1c7 cells by radish sprouts, Raphanus sativus L. J Food Sci. 2006;71(2):144-8

21. Barillari J, Cervellati $R$, Paolini $M$, Tatibouet $A$, Rollin $P$, lori $R$. Isolation of 4-methylthio-3-butenyl glucosinolate from Raphanus sativus sprouts (Kaiware Daikon) and its redox properties. J Agric Food Chem. 2005;53(26):9890-6.

22. Bozin BN, Mimica-Dukic SI, Goran A, Igic R. Phenolis as antioxant in garlic (Allium sativum L, Alliaceae). Food Chemistry. 2008;111:925-9.

23. Nanchen I, Chang CC, Chai NgC, Wang CY, Shyu YT, Chang TL. Antioxidant and antimicrobial activity of Zingiberaceae plants in Taiwan. Plants Foods Hum Nutr. 2007;63:15-20.

24. Borowski J, Szajdek A, Borowska EJ, Ciska E, Zielinski H. Content of selected bioactive components and antioxidant properties of broccoli (Brassica oleraceae L.). European Food Research Technology. 2007:226:459-65.

25. Tiveron AP, Melo PS, Bergamaschi BK, Vieira TMF, Regitano-d'Acre MAB, Alencar MS. Antioxidant activity of Brazilian vegetables and its relation with phenolic composition. Int J Mol Sci. 2012;13:8943-57.

26. Rice-Evans CA, Miller NT, Paganga G. Antioxidant properties of phenolic compounds. Trends in Plant Sciences. 1997;4:304-9.

27. Bors MD, Socaci SA, Tofana MV, Pop AV, Nagy M, Vliac R. Determination of total phenolics, flavonoids and antioxidant capacity of methanolic extracts of some brassica seeds. Bulletin UASVM Food Science and Technology. $2014 ; 71(2): 205-6$
28. Pajak P, Socha R, Galkowska D, Roznowski J, Fortuna T. Phenolic profile and antioxidant activity in selected seeds and sprouts. Food Science. 2014;143:300-6.

29. Ayaz FA, Ayaz SH, Karaglou SA, Gruz J, Valentova K, Ulrichova J, et al. Phenolic contents of kale (Brassica oleraceae L, var acephala D.C.) extracts and their antioxidants and antibacterial activities. Food Chemistry. 2008;107:19-25.

30. Khokhar S. Magnusdottir SGM. Total phenol, catechin, and caffeine contents of teas commonly consumed in United Kingdom. J Agric Food Chem. 2002;50:565-70.

31. Balasundaram N, Sudram K, Samman S. Phenolic compounds in plants and agri- industrial by-products, antioxidant activity, occurrence and potential uses. Food Chemistry. 2006;99:191-203.

32. Baenas N, Diego A. Selecting sprouts of Brassicaceae for optimum phytochemical composition. Journal of Agriculture and Food Chemistry 2012;60:11409-20

33. Hollman PCH, Arts ICW. Flavanols, flavones and flavanols-Nature, occurrence and dietary burden. J Agric Food Chem. 2010;80:1081-93.

34. Koksal F, Gulcin I. Antioxidant activity of cauliflower (Brassica oleraceae L,) Turkish Journal of Agriculture Forum. 2008;32:65-78.

35. Hanlon PR, Barnes DM. Phytochemical composition and biological activity of 8 varieties of radish (Raphanus sativus L.). Sprouts and mature taproots. Journal of Food Science. 2010;76:185-92.

\section{GRAPHICAL ABSTRACT}

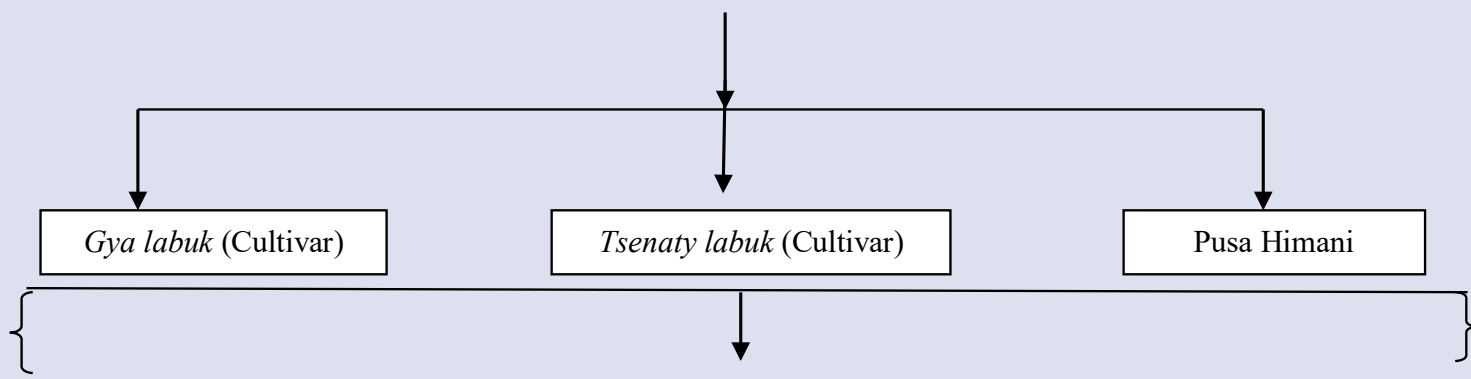

(ROOT, LEAF, PEEL, SEED AND SPROUTS)

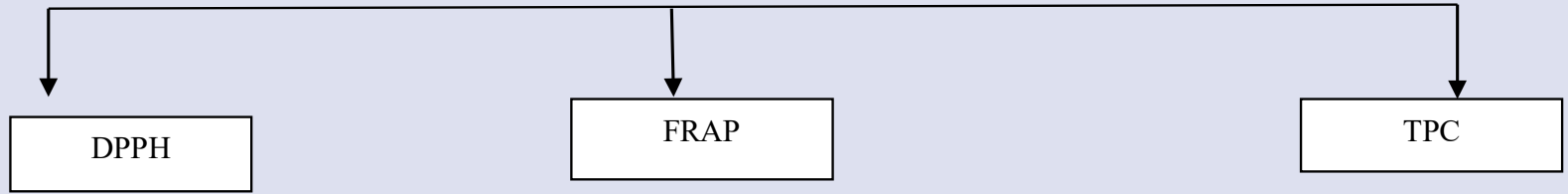

\section{Gya labuk}

Maximum value-leaf

Minimum value- peel

Tsenaty labuk

Maximum value-leaf

Minimum value- peel

Pusa Himani

Maximum value-leaf

Minimum value- peel
Gya labuk

Maximum value-leaf

Minimum value- peel

Tsenaty labuk

Maximum value-leaf

Minimum value- pee

Pusa Himani

Maximum value-leaf

Minimum value- peel

The values were statistically significant at $p<0.05$ 


\section{ABOUT AUTHORS}

Ms Sonam Chorol, received her MSc (Botany) from Mysore University. Worked as Senior Research fellow at DRDO-Defence Institute of High Altitude Research, Leh and currently working as a RA at Wildlife Department, Leh.

Cite this article: Chorol S. Antioxidant Content in Different Parts of Radish (Raphanus sativus L.) from Cold Arid Ladakh region of Trans- Himalaya (Jammu and Kashmir). Pharmacog J. 2019;11(5):1064-70. 